\title{
A War of Songs: Popular Music and Recent Russia-Ukraine Relations
}

Arve Hansen, Andrei Rogatchevski, Yngvar Steinholt \& David-Emil Wickström med förord av Artemy Troitsky

Soviet and Post-Soviet Politics and Society, vol. 203

Stuttgart: ibidem-Verlag 2019

258 sidor. ISBN 9783838211732

Recenserad av Maria Engström [Docent i slaviska språk, universitetslektor i ryska, Institutionen för moderna språk, Uppsala universitet, maria.engstrom@moderna. uu.se]

Boken $A$ War of Songs: Popular Music and Recent Russia-Ukraine Relations publicerad 2019 av ibidem-Verlag är den första vetenskapliga publikationen som undersöker musikens roll och funktion i den pågående rysk-ukrainska ideologiska och militära konflikten. Den är skriven av fyra norska forskare - Arve Hansen, Andrei Rogatchevski, Yngvar Steinholt och David-Emil Wickström - som ingår i forskargruppen Russian Space: Concepts, Practices, Representations vid Universitetet i Tromsø. Boken består av ett kort förord, en introduktion som presenterar bokens struktur, fyra kapitel, ett kort efterord, bibliografi och index. Förordet är skrivet av den kände ryske musikkritikern Artemy Troitsky, som numera är bosatt i Estland.

Kapitel 1 Pop Rock, Ethno-Chaos, Battle Drums and a Requiem (s. 33-86) är det längsta kapitlet (53 sidor) och erbjuder en detaljerad undersökning av musikens roll i massprotesterna i Ukraina under Euromajdan i Kiev 2013-2014. Författarna börjar med att beskriva musikens roll i den långa raden av protester i Ukraina sedan Sovjetunionens fall samt sociala mediers och musikvideors mobiliserande roll under protesterna. Vidare identifieras fem faser under Euromajdan och fem sånger som representerar revolutionens olika etapper analyseras ( $\mathrm{t}$ ex Okean Elzys »Vstavaj» kopplas till den första optimistiska fasen medan Klofelins "Horila shyna» till den tredje, våldsamma fasen). Kapitlet innehåller korta musikologiska kommentarer till de studerade sångerna. Fokus ligger på Euromajdan, men musiken under AntiEuromajdan-protesterna nämns.

Kapitel 2 Euromaidan's Aftermath and the Genre of Answer Song (s. 87-126) är lite kortare (39 sidor) och fokuserar på ett viktigt fenomen inom den ukrainsk-ryska konflikten, nämligen de så kallade "svarssångerna». Efter en kort, men informerande presentation av denna genre erbjuder författarna en djup och nyanserad analys av flera välkända sånger vars ukrainska och ryska textvarianter reflekterar motsatta 
ideologiska och (geo)politiska intressen. Både nya sånger som skrevs i samband med Rysslands annektering av Krimhalvön (t ex Anastasija Dmytruks "Nikogda my ne budem bratjami» från mars 2014 och det ryska "svaret» skrivet av Leonid och Gleb Kornilov från april 2014) och remakes av gamla sovjetiska sånger analyseras (t ex Michail Tanichs "Idet soldat po gorodu» från 1978 och Orest Ljutyjs parodierande svar "Ide katsap po gorodu» från 2014).

Kapitel 3 Exposing the Fault Lines Beneath the Kremlin's Restorative Geopolitics: Russian and Ukrainian Parodies of the Russian National Anthem (s. 127-162) är på 35 sidor och fokuserar på ryska och ukrainska satiriska pastischer på den ryska nationalsången. Efter en genomgång av den ryska nationalsångens historia presenteras sex parodier skrivna mellan 2009 och 2014. Tyvärr till skillnad från kapitel 1 och 2 citeras inte de analyserade parodierna, vilket gör att det blir svårare att följa författarnas resonemang. Dessutom är inte alla sånger som tas upp i analysen kopplade till den aktuella ukrainsk-ryska konflikten som volymen fokuserar på.

Kapitel 4 "Lasha Tumbai», or "Russia, Good-Bye» - The Eurovision Song Contest as a Post-Soviet Geopolitical Battleground (s.163-198) är det sista kapitlet i boken och är 35 sidor långt. I detta kapitel diskuteras Ukrainas och Rysslands bidrag till Eurovision i ett politiskt perspektiv, och musiken tolkas som ett exempel på kulturdiplomati och ett mäktigt ideologiskt instrument i den nationella identitetsformationen. Författarna diskuterar den rysk-ukrainska ideologiska kampen genom att göra en komparativ analys av Ukrainas och Rysslands sånger som deltog i Eurovision efter den Orangea revolutionen 2004, t ex GreenJollys »Razom nas bahato» och Natalia Podolskajas »Nobody Hurt No One» (2005), Verka Serduchkas "Lasha Tumbai» och Serebros "Song\#1" (2007), Jamalas "1944» och Sergej Lazarevs "You are the only one» (2016) $\mathrm{mm}$.

I introduktionen poängterar författarna att boken är ett resultat av kollektiv forskning och inte är en samling av fyra individuella forskningsinsatser. Det är dock uppenbart att kapitlen är skrivna av olika forskare med skilda akademiska språk och olika teoretiska och metodologiska grepp, vilket bidrar till en viss analytisk obalans i volymen. I noter till varje kapitel preciseras vems fältforskning som kapitlet i frågan baseras på och/eller vem som har översatt citat (kapitel 1 - Arve Hansen, kapitel 2 Andrei Rogatchevski, kapitel 3 - Yngvar Steinholt, kapitel 4 - David-Emil Wickström), vilket hjälper den nyfikne läsaren att lista ut huvudförfattaren till varje kapitel. Som kritik kan man också nämna inkonsekvent citering (till skillnad från kapitel 1, 2 och 4 saknas längre citat på originalspråket och i översättning i kapitel 3) och att kapitel 3 och 4 har olika titlar i innehållsförteckningen och i själva kapiteltexten.

Trots dessa mindre brister utgör denna kollektiva monografi ett mycket intressant och viktigt bidrag till ett expanderande forskningsfält som fokuserar på politiska och sociala aspekter av populärkulturen. Boken introducerar ett aktuellt och föga studerat källmaterial och kan med fördel användas i undervisningen på grund- och avancerad nivå vid universitet och högskolor. 